\title{
Internal Factors Affecting Islamic Banking Financing for Micro, Small, and Medium Enterprises
}

\author{
Rusdi Hidayat Nugroho ${ }^{1}$, Sonja Andarini ${ }^{2}$, Franky Nasution ${ }^{3}$, Nurul Aqidatul Izzah ${ }^{4}$ \\ \{rusdi_hidayat.adbis@upnjatim.ac.id ${ }^{1}$,sonja_andarini@upnjatim.ac.id ${ }^{2}$ \} \\ Universitas Pembangunan Nasional "Veteran" Jawa Timur, Indonesia ${ }^{1,2,3,4}$
}

\begin{abstract}
The Islamic banking is one alternative in overcoming the phenomenon of a country's economic inequality. This is seen from its intermediation function as a channel for funds for Micro, Small and Medium Enterprises (MSME) for the sake of economic stability. This study aims to analyze the internal factors that influence Islamic banking financing for MSME in Indonesia. This type of research is quantitative research with secondary data. The cross-section data includes the Islamic Banking data in Indonesia, while the time series data covers the data from the first quarter of 2014 to the fourth quarter of 2018. Furthermore, the data were analyzed using panel data regression with the Fixed Effect Model (FEM). Based on the results of the analysis, it shows that the Capital Adequacy Ratio (CAR) and Non-Performing Financing (NPF) factors has a positive and significant effect on MSME financing. While Operational Costs Operating Income (BOPO) and Financing to Deposit Ratio (FDR) has a negative and significant effect on MSME financing. Then the CAR, BOPO, NPF and FDR factors influence simultaneously and significantly towards MSME financing. Thus, this research can be used in strategic policy planning for related parties to develop MSME in Indonesia.
\end{abstract}

Keywords: Islamic Banking, Internal Factors, MSME Financing, Panel Data Regression, FEM.

\section{Introduction}

The banking is a financial intermediary institution (Financial Intermediates) channeling funds from parties with excess money (Surplus) to those who lack funds (Deficit) with a specified time. Banking has a function as a collector and distributor public funds. So banking is also referred to as a public trust institution (Agent of Trust). In addition to functioning as an Agent of Trust, banking also functions for national economic development (Agent of Development) in the context of increasing equity, economic growth and national stability.

Financial sector plays an important role in driving a country's economic growth [1]. One alternative in overcoming the phenomenon of economic inequality is Islamic banking. Islamic banking is a banking product based on the Islamic economic system [2].

The Islamic banking plays an active role in helping the development of MSME in Indonesia. Islamic banking in Indonesia in its intermediation function also allocates financing to MSME. 


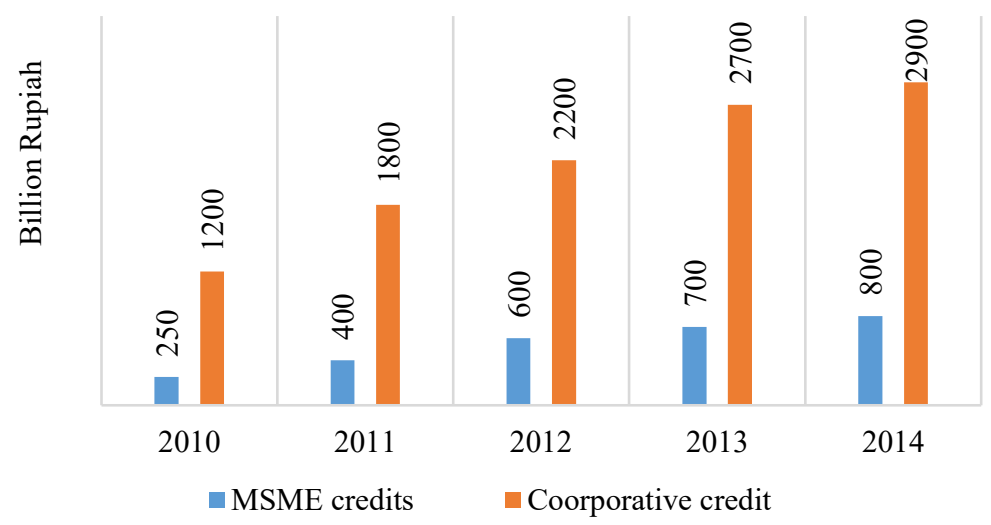

Graph. 1. Graph of the development of MSME and corporate loans in 2016-2017 Source: Indonesia's ministry of cooperatives and small and medium enterprises (KUKM).

Table 1. Development of business units in MSME in 2016-2017

\begin{tabular}{clll}
\hline No. & \multicolumn{1}{c}{ Indicator } & \multicolumn{1}{c}{ Amount (Unit) } & \multicolumn{1}{c}{ Segment (\%) } \\
\hline 1 & Micro enterprises & 1.243 .322 & 2,04 \\
\hline 2 & Small enterprises & 26.043 & 3,56 \\
\hline 3 & Medium enterprises & 2.075 & 3,67 \\
\hline
\end{tabular}

Source: Indonesia's ministry of cooperatives and small and medium enterprises (KUKM).

MSME demonstrate the ability to survive even in the face of a crisis. Companies are required to determine the appropriate strategy in order to survive and win in the competition so that the objectives of the company can be reached [3]. The ability of MSME to survive with personal resources makes many feel optimistic that at present and in the future MSME are a milestone for the savior of the national economy [4].

Table 2. Development of gross domestic product (GDP) at constant prices in MSME in 2016-2017

\begin{tabular}{clcl} 
No. & \multicolumn{1}{c}{ Indicator } & Amount (Billion) & Segment (\%) \\
\hline 1 & Micro enterprises & $119.994,0$ & 4,38 \\
\hline 2 & Small enterprises & $98.739,3$ & 6,12 \\
\hline 3 & Medium enterprises & $65.617,8$ & 5,00 \\
\hline
\end{tabular}

Source: Indonesia's ministry of cooperatives and small and medium enterprises (KUKM).

To empower MSME, the roles of government, financial institutions and business actors are needed. Especially it concerns implementation of a predictive assessment of stability of the enterprise system development as an important role of SMEs in formation of the gross domestic product (GDP) of the state should be noticed [5].

Judging from the forms of financing offered to Islamic banking according to Karim [6], namely financing with the principle of buying and selling, rental principles, profit sharing principles, and supplementary contracts.

The research objectives are; (1) find out and analyze the influence partially (positive / negative) of internal factors on Islamic Banking financing for MSME in Indonesia and (2) find out and analyze the influence simultaneously of all internal factors on Islamic Banking financing for MSME in Indonesia. 


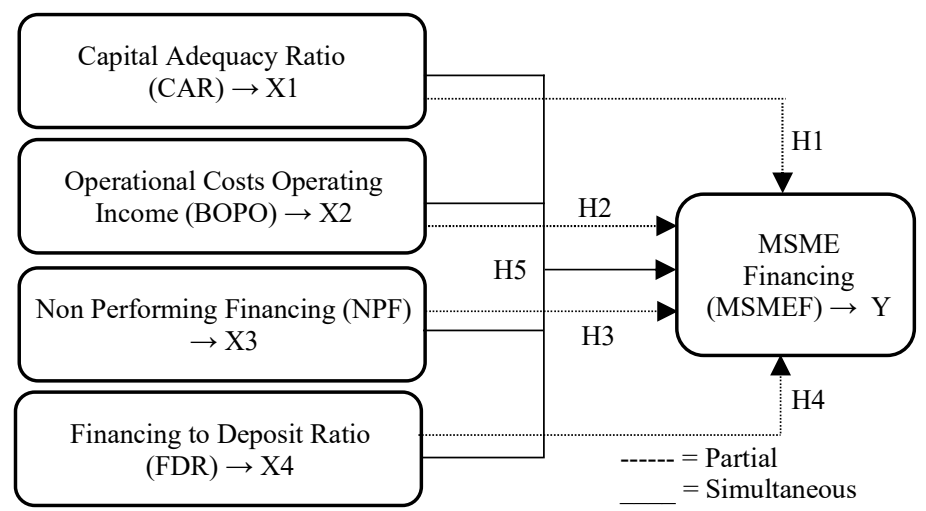

Fig. 1. Research framework

The hypotheses in this study are; (1) CAR has a positive and significant effect on MSMEF, (2) BOPO has a negative and significant effect on MSMEF, (3) NPF has positive and significant effect on MSMEF, (4) FDR has a negative and significant effect on MSMEF, and (5) CAR, BOPO, NPF, and FDR factors influence simultaneously and significantly towards MSMEF.

\section{Research Methods}

\subsection{General description of research}

\subsubsection{Type of research}

This type of research is quantitative research. In this study, the data studied were secondary data. The cross-section data includes the data from Islamic Commercial Banks (BUS) in Indonesia. While the time series data includes data from quarter I 2014 until quarter IV 2018. Data obtained from several sources include; BUS, Financial Services Authority (OJK), Ministry of KUKM, research paper, books and other reliable reference sources. The data is processed by EViews 10 software.

\subsubsection{Research variables}

The independent variable (independent) in this study is an internal factor, namely CAR (X1), BOPO (X2), NPF (X3), and FDR (X4). Meanwhile, the dependent variable in this study is $\operatorname{MSMEF}(\mathrm{Y})$.

\subsubsection{Research sample}

This study uses a sampling technique by purposive sampling. The number of research samples are 11 Islamic Commercial Banks (BUS) which retrieve them one by one from each 
bank and registered in OJK. This is criteria based on the selection on the completeness of the each bank data from annual finance reports during the study period (2014 - 2018).

Table 3. Research samples from BUS

\begin{tabular}{cl}
\hline No. & \multicolumn{1}{c}{ Company Names } \\
\hline 1. & PT. Bank Syariah Mandiri. Tbk \\
\hline 2. & PT. Bank BNI Syariah. Tbk \\
\hline 3. & PT. Bank BRI Syariah. Tbk \\
\hline 4. & PT. Bank Jabar Banten Syariah. Tbk \\
\hline 5. & PT. Bank Aceh Syariah, Tbk \\
\hline 6. & PT. Bank Muamalat Indonesia. Tbk \\
\hline 7. & PT. Bank Maybank Syariah Indonesia. Tbk \\
\hline 8. & PT. Bank Syariah Bukopin. Tbk \\
\hline 9. & PT. Bank BCA Syariah. Tbk \\
\hline 10. & PT. Bank Panin Dubai Syariah. Tbk \\
\hline 11. & PT. Bank Mega Syariah. Tbk
\end{tabular}

Source: Indonesia's Financial Services Authority [7].

\subsection{Regression model selection test}

\subsubsection{Chow test}

Chow test is used to determine the best test method between the two methods namely the common effect model (CEM) or fixed effect model (FEM) which will be used in panel data modeling [8].

a) The hypothesis used is:

$-\mathrm{H}_{0}$ : CEM

$-\mathrm{H}_{1}$ : FEM

b) The decision used is:

- If the value of prob. $\mathrm{F}>0.05$ then $\mathrm{H} 0$ is accepted and $\mathrm{H} 1$ is rejected.

- If the value of prob. $\mathrm{F}<0.05$ then $\mathrm{H}_{0}$ is rejected and $\mathrm{H}_{1}$ is accepted.

c) The formula used is:

$$
C H O W=\frac{(E S S 1-E S S 2) /(N-1)}{(E S S 2) /(N T-N-K)}
$$

$$
\begin{aligned}
& \text { Information: } \\
& \text { ESS1= Residual sun square alleged FEM } \\
& \text { ESS2 = Residual sun square alleged CEM } \\
& \mathrm{N} \quad=\text { Amount of cross section } \\
& \mathrm{T} \quad=\text { Amount of time series } \\
& \mathrm{K} \quad=\text { Amount of explanatory variables }
\end{aligned}
$$

\subsubsection{Hausman test}

Hausman test is used to determine the best test method between the two methods namely fixed effect model (FEM) or random effect model (REM) which will be used in panel data modeling [8].

a) The hypothesis used is: 
$-\mathrm{H}_{0}: \mathrm{REM}$

$-\mathrm{H}_{1}$ : FEM

b) The decision used is:

- If the value of prob. Chi-Square $>0.05$ then $\mathrm{H}_{0}$ is accepted and $\mathrm{H}_{1}$ is rejected.

- If the value of prob. Chi-Square $<0.05$ then $\mathrm{H}_{0}$ is rejected and $\mathrm{H}_{1}$ is accepted.

c) The formula used is:

$$
\text { HAUSMAN }=(\beta-b)(M 0-M 1)^{-1}(\beta-b) \sim X^{2}(\mathrm{~K})(2)
$$

Information:

$\beta=$ Vector for FEM variable statistics

$\mathrm{b}=$ Vector for REM variable statistics

$\mathrm{M} 0=$ Alleged covariance matrix FEM

$\mathrm{M} 1=$ Alleged covariance matrix REM

\subsection{Classic assumptions test}

\subsubsection{Multicollinearity test}

Multicollinearity test is used to test whether in the regression model, there is a correlation between independent variables [9].

a) The hypothesis used is:

$-\mathrm{H}_{0}$ : Multicollinearity occurs

$-\mathrm{H}_{1}$ : No multicollinearity occurs

b) The decision used is:

- If the value of $\mathrm{r}>0.9$ then $\mathrm{H} 0$ is accepted and $\mathrm{H} 1$ is rejected.

- If the value of $\mathrm{r}<0.9$ then $\mathrm{H}_{0}$ is rejected and $\mathrm{H}_{1}$ is accepted.

\subsubsection{Heteroscedasticity test}

Heteroscedasticity test is used to test whether in the regression model, there is an unequal variance from the residuals of one observation to another [9].

a) The hypothesis used is:

$-\mathrm{H}_{0}$ : Heteroscedasticity occurs

$-\mathrm{H}_{1}$ : No heteroscedasticity occurs

b) The decisions used are:

- If residuals are heteroscedastic then $\mathrm{H}_{0}$ is accepted and $\mathrm{H}_{1}$ is rejected.

- If Residuals are homoscedastic then $\mathrm{H}_{0}$ is rejected and $\mathrm{H}_{1}$ is accepted.

\subsection{Regression model test}

The regression model test is using panel data regression which is an analytical method to show differences between individuals as seen from the difference in their constants.

The formula used is:

$$
Y=\alpha+\beta 1 X 1 \text { it }+\beta 2 X 2 \text { it }(\mathfrak{\Re}) \beta 3 X 3 \text { it }+\beta 4 X 4 i t+\varepsilon
$$




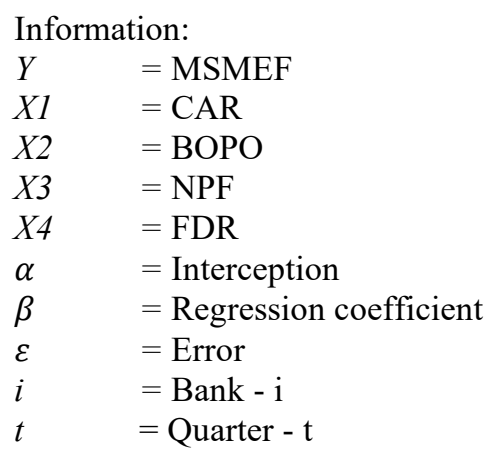

\subsection{Hypothesis test}

\subsubsection{Partial test}

Partial test ( $\mathrm{t}$ ) is used to determine whether some independent variables individually have a significant influence on the dependent variable [10].

a) The hypothesis used is:

$-\mathrm{H}_{0}$ : There is no significant effect of the independent variable on the dependent variable

$-\mathrm{H}_{1}$ : There is a significant effect of the independent variable on the dependent variable

b) The decision used is:

- If the value of $-\mathrm{t}$ statistic $<\mathrm{t}$ table $>\mathrm{t}$ statistic and the value of prob. $>$ significance level, $\mathrm{H} 0$ is accepted and $\mathrm{H} 1$ is rejected.

- If the value of $-\mathrm{t}_{\text {statistic }}<\mathrm{t}_{\text {table }}$ or $\mathrm{t}_{\text {statistic }}>\mathrm{t}_{\text {table }}$ and the value of prob. $<$ the significance level then $\mathrm{H}_{0}$ is rejected and $\mathrm{H}_{1}$ is accepted.

The formula used is:

$$
t={\frac{r \sqrt{n-2}}{\sqrt{1-R^{2}}}}^{(4)}
$$

Information:

$$
\begin{array}{ll}
\mathrm{t} & =\mathrm{t} \text { distribution } \\
\mathrm{r} & =\text { Partial correlation coefficient } \\
\mathrm{R}^{2} & =\text { Coefficient of determination } \\
\mathrm{n} & =\text { Amount of data }
\end{array}
$$

\subsubsection{Simultaneous test}

Simultaneous test $(\mathrm{F})$ is used to determine whether all independent variables simultaneously have a significant effect on the dependent variable [10].

a) The hypothesis used is:

$-\mathrm{H} 0$ : There is no significant effect of all independent variables on the dependent variable

$-\mathrm{H} 1$ : There is a significant effect of all independent variables on the dependent variable 
b) The decision used is:

- If the value $\mathrm{F}$ statistic $<\mathrm{F}$ table and the prob value. $>$ significance level, H0 is accepted and $\mathrm{H} 1$ is rejected.

- If the value of $\mathrm{F}$ statistic $>\mathrm{F}$ table and the value of prob. $<$ the significance level then $\mathrm{H} 0$ is rejected and $\mathrm{H}_{1}$ is accepted.

c) The formula used is:

Information:

$$
F=\frac{R^{2} / k(5)}{\left(1-R^{2}\right) /(n-k-1)}
$$

$\mathrm{F}=\mathrm{F}$ value

$\mathrm{R}^{2}=$ Coefficient of determination

$\mathrm{k}=$ Amount of variables

$\mathrm{n}=$ Amount of data

\section{Results and Discussion}

\subsection{General description of company}

The general description of the company in the study is an Islamic Commercial Bank that matches the study sample and is registered with the Indonesian Financial Services Authority. Furthermore, testing and analysis of the research results will be carried out in stages.

\subsection{Analysis of regression model selection test}

\subsubsection{Analysis of chow test}

Table 4. Chow test results

\begin{tabular}{llll}
\hline Effects Test & Statistic & d.f. & Prob. \\
\hline Cross-section F & 164.381081 & $(10,205)$ & 0.0000 \\
\hline Cross-section Chi-square & 483.843344 & 10 & 0.0000 \\
\hline
\end{tabular}

Based on the table 4, the value of prob. F equal to $(0.00)<(0.05)$ then $\mathrm{H}_{0}$ is rejected and $\mathrm{H}_{1}$ is accepted. This means that the most appropriate model is FEM.

\subsubsection{Analysis of Hausman test}

Table 5. Hausman test results

\begin{tabular}{llll}
\hline Test Summary & Chi-Sq. Statistic & Chi-Sq. d.f. & Prob. \\
\hline Cross-section random & 9.890078 & 4 & 0.0423 \\
\hline
\end{tabular}

Based on the table 5, the value of prob. Chi-Square of $(0.04)<(0.05)$ then $\mathrm{H}_{0}$ is rejected and $\mathrm{H}_{1}$ is accepted. This means that the most appropriate model is FEM. 


\subsection{Analysis of classic assumptions test}

\subsubsection{Analysis of multicollinearity test}

Table 6. Multicollinearity test results

\begin{tabular}{ccccc}
\hline & $\mathbf{X 1}$ & $\mathbf{X 2}$ & $\mathbf{X 3}$ & $\mathbf{X 4}$ \\
\hline $\mathbf{X 1}$ & 1.000000 & -0.197226 & -0.284872 & -0.038645 \\
\hline $\mathbf{X 2}$ & -0.197226 & 1.000000 & 0.545869 & -0.137104 \\
\hline $\mathbf{X 3}$ & -0.284872 & 0.545869 & 1.000000 & -0.090575 \\
\hline $\mathbf{X} 4$ & -0.038645 & -0.137104 & -0.090575 & 1.000000 \\
\hline
\end{tabular}

Based on the table 6 , all values of $r<0.9$ then $\mathrm{H}_{0}$ is rejected and $\mathrm{H}_{1}$ is accepted. This means that there is no multicollinearity occurs.

\subsubsection{Analysis of heteroscedasticity test}

Table 7. Heteroscedasticity test results

Panel Cross-section Heteroskedasticity LR Test

Null hypothesis: Residuals are homoscedastic

Panel Period Heteroskedasticity LR Test

Null hypothesis: Residuals are homoscedastic Specification: Y C X1 X2 X3 X4

Based on the table 7, Residuals are Homoscedastic then $\mathrm{H}_{0}$ is rejected and $\mathrm{H}_{1}$ is accepted. This means that no heteroscedasticity occurs.

\subsection{Analysis of regression model test}

Table 8. Panel data regression test results

\begin{tabular}{cccc}
\hline Variable & Coefficient & Std. Error & Prob. \\
\hline C & 0.7139506. & 437504.2 & 0.0000 \\
\hline X1 & 0.71721 .30 & 9679.691 & 0.0000 \\
\hline X2 & -0.8394 .049 & 3816.305 & 0.0290 \\
\hline X3 & 0.32248 .92 & 9985.054 & 0.0014 \\
\hline X4 & -0.9325 .172 & 1540.772 & 0.0000 \\
\hline
\end{tabular}

Equation of regression results:

$$
Y=0.713+0.717 \times 1 \text { it }-0.839 \times 2 \text { it }+0.322 \times 3 \text { it }-0.932 X 4 i t+\varepsilon
$$

(1) X1 variable has a positive effect on $Y$ with a coefficient of 0.717 . If X1 increases by 1 unit, it will increase Y by 0.717 . (2) X2 variable has a negative effect on $\mathrm{Y}$ with a coefficient of -0.839 . If X2 increases by 1 unit, it will decrease $\mathrm{Y}$ by -0.839 . (3) X3 variable has a positive effect on $\mathrm{Y}$ with a coefficient of 0.322 . If $\mathrm{X} 3$ increases by 1 unit it will increase $\mathrm{Y}$ by 0.322 . (4) X4 variable has a negative effect on $\mathrm{Y}$ with a coefficient of $-0,932$. If $\mathrm{X} 4$ increases by 1 unit, it will decrease $\mathrm{Y}$ by $-0,932$. 


\subsection{Analysis of hypothesis test}

\subsubsection{Analysis of partial test}

Table 9. Partial test results

\begin{tabular}{cccc}
\hline Variable & t-statistic & Std. Error & Prob. \\
\hline C & 16.31872 & 437504.2 & 0.0000 \\
\hline X1 & 7.409462 & 9679.691 & 0.0000 \\
\hline X2 & -2.199523 & 3816.305 & 0.0290 \\
\hline X3 & 3.229719 & 9985.054 & 0.0014 \\
\hline X4 & -6.052274 & 1540.772 & 0.0000 \\
\hline
\end{tabular}

$\mathrm{H} 1=\mathrm{X} 1 \rightarrow \mathrm{Y}$

$\mathrm{X} 1$ variable has a $\mathrm{t}_{\text {statistic }}$ of 7.409 with a prob level. 0.00. By using a significance level of 0.05. Because the value of $t_{\text {statistic }}(7.409)>t_{\text {table }}(1.943)$ and prob. $(0.00)<$ sig. $(0.05)$ then $\mathrm{H}_{0}$ is rejected and $\mathrm{H}_{1}$ is accepted. This means that the CAR hypothesis has a positive and significant effect on MSMEF accepted. This shows that if the CAR value is high, the bank is able to meet capital and cover credit risk and be able to make a high contribution to MSME financing.

$\mathrm{H} 2=\mathrm{X} 2 \rightarrow \mathrm{Y}$

$\mathrm{X} 2$ variable has a $\mathrm{t}_{\text {statistic }}$ of -2.199 with a prob level. 0.02. By using a significance level of 0.05 . Because the value of $t_{\text {statistic }}(-2.199)<t$ table $(-1.943)$ and prob. $(0.02)<$ sig. $(0.05)$ then $\mathrm{H}_{0}$ is rejected and $\mathrm{H} 1$ is accepted. This means that the BOPO hypothesis has a negative and significant effect on MSMEF accepted. This shows that if the BOPO value is high, the bank will minimize the risk of operational activities and not provide a high contribution to MSME financing.

$\mathrm{H} 3=\mathrm{X} 3 \rightarrow \mathrm{Y}$

$\mathrm{X} 3$ variable has a $\mathrm{t}_{\text {statistic }}$ of 3.229 with a prob level. 0.00. By using a significance level of 0.05 . Because the value of $t_{\text {statistic }}(3.222)>t_{\text {table }}(1.943)$ and prob. $(0.00)<$ sig. $(0.05)$ then $\mathrm{H}_{0}$ is rejected and $\mathrm{H}_{1}$ is accepted. This means that the NPF hypothesis has a positive and significant effect on MSMEF accepted. This shows that if the NPF value is high then the bank will be ready to deal with non-performing loans and be able to make a high contribution to MSME financing.

$\mathrm{H} 4=\mathrm{X} 4 \rightarrow \mathrm{Y}$

$\mathrm{X} 4$ variable has a $\mathrm{t}_{\text {statistic }}$ of -6.052 with a prob level. 0.00 . By using a significance level of 0.05 . Because the value of $t_{\text {statistic }}(-6.052)<t$ table $(-1.943)$ and prob. $(0.00)<$ sig. (0.05) then $\mathrm{H}_{0}$ is rejected and $\mathrm{H}_{1}$ is accepted. This means that the FDR hypothesis has a negative and significant effect on MSMEF accepted. This shows that if the FDR value is high, the bank will support primary investment and not provide a high contribution to MSME financing.

\subsubsection{Analysis of simultaneous test}

Table 10. Simultaneous test results 


\begin{tabular}{ll}
\hline R-squared & $\mathbf{0 . 9 7 9 6 8 8}$ \\
\hline Adjusted R-squared & 0.978301 \\
\hline S.E. of regression & 0.964714 \\
\hline F-statistic & 706.2564 \\
\hline Prob(F-statistic) & 0.000000 \\
\hline
\end{tabular}

$\mathrm{H} 5=\mathrm{X} 1, \mathrm{X} 2, \mathrm{X} 3$, dan $\mathrm{X} 4 \rightarrow \mathrm{Y}$

Based on the table 10, it shows that coefficient determination of R-squared is $(0.97)=$ $97 \%$ and the $\mathrm{F}_{\text {statistic }}$ is 706.2564 with a prob level. 0.00 . By using a significance level of 0.05 . Because the value of $F_{\text {statistic }}(706.2564)>F_{\text {table }}(4.53)$ and prob $\mathrm{F}(0.00)<$ sig. $(0.05)$ then $\mathrm{H}_{0}$ is rejected and $\mathrm{H}_{1}$ is accepted. This means that the CAR, BOPO, NPF, and FDR factors hypothesis influence simultaneously and significantly towards MSMEF accepted. This shows that these internal factors greatly affect MSME financing.

\section{Conclusions}

Based on the results and discussion, it can be concluded that the CAR and NPF factors has a positive and significant effect on MSMEF. Whereas BOPO and FDR has a negative and significant effect on MSMEF. Then the CAR, BOPO, NPF, and FDR factors influence simultaneously and significantly towards MSMEF.

\section{References}

[1] S. El Ayyubi, L. Anggraeni, and A. D. Mahiswari, "Pengaruh bank syariah terhadap pertumbuhan ekonomi di Indonesia," Al-Muzara'ah, vol. 5, no. 2, pp. 88-106, 2017.

[2] A. Marimin and A. H. Romdhoni, "Perkembangan Bank Syariah Di Indonesia," J. Ilm. Ekon. Islam, vol. 1, no. 2, 2017.

[3] H. N. Rusdi, B. W. Otok, and K. Roy, "Moderating entrepreneurship at corporate reputation in business performance using partial least square," Int. J. Mech. Eng. Technol., vol. 9, no. 9, pp. 348-358, 2018.

[4] Muhammad, Metodologi Penelitian Ekonomi Islam. Jakarta: Rajawali Pers, 2015.

[5] S. V. Levushkina, R. V. Miroshnichenko, V. V. Kurennaya, and E. G. Agalarova, "Program development of small and medium enterprises in Stavropol region of the Russian federation," Int. J. Econ. Financ. Issues, vol. 6, no. 2S, pp. 151-157, 2016.

[6] Adiwarman Karim, "BANK ISLAM : Analisis Fiqih dan Keuangan," in Edisi Keempat, 2011.

[7] Otoritas Jasa Keuangan, "Laporan Statistik Perbankan Syariah (BUS)," 2019. [Online]. Available: http://www.ojk.go.id.

[8] A. T. Basuki and N. Prawoto, "Analisis Regresi Dalam Penelitian Ekonomi \& Bisnis: Dilengkapi Aplikasi SPSS \& EVIEWS,” Depok PT Rajagrafindo Persada, 2016.

[9] M. Kuncoro, "Metode Riset untuk Bisnis dan Ekonomi (Edisi ke-4)," Jakarta: Erlangga, 2014.

[10] I. Ghozali, Aplikasi Analisis Multivariat dengan Program IBM SPSS 21, 7th ed. Semarang: Penerbit Universitas Diponegoro, 2013. 